\title{
Micro-Retail Enterprises in China: Change and Continuity
}

\author{
Walter Huber \\ Muskingum University, Ohio, USA \\ Yufeng Sun \\ North China Institute of Science and Technology, Beijing, China \\ Shizhou Feng, Anyi Wang, Zijing Xu \\ Muskingum University, Ohio, USA/North China Institute of Science and Technology, Beijing, China
}

\begin{abstract}
Micro-retail enterprises (MREs) have had to adapt to changing conditions in regards to mobile payments (m-payments) and access to loans. The authors built on the published results of two previous surveys of MREs. One thousand nine hundred and ninety-eight MREs in four cities in China were surveyed in May and June of 2018 to determine the use and importance of m-payments to their business, their access to loans, and patterns of entrepreneurship. While some trends remain unchanged, at least two significant findings emerge. M-payments have not only gained almost universal acceptance by MREs in China; they are the overwhelmingly preferred payment method. In our last paper, we argued that "m-payments may represent a form of leapfrogging technology which will spur growth in this sector" and this paper provides additional evidence this is occurring. M-payments show every sign of being an example of a leapfrogging technology that is quickly changing the rules for retail in the MRE sector and opening new opportunities for businesses while lowering transaction costs, reducing fraud, and improving customer satisfaction. There are intriguing implications, including changes to the pace of m-payments replacing credit cards. Second, while it remains true that overall, access to loans for MREs is limited; there is a great deal of variation between tier-one cities and tier-two and tier-three cities.
\end{abstract}

Keywords: micro-retail enterprise (MRE), mobile payment (m-payment), Chinese entrepreneur, leapfrogging technology, access to loans

In China's retail sector, the pace of change has been quite fast in some ways and rather slow in others. This paper looks at micro-retail enterprises (MREs) and how this important sector of the small to medium sized enterprises (SMEs) sector has adapted to changing conditions in regards to mobile payments (m-payments) and

Corresponding author: Walter Huber, Ph.D., professor, Department of Political Science and Criminal Justice, Muskingum University, Ohio, USA; research fields: education policy, economic policy, political economy, comparative public policy.

Yufeng Sun, M.A., chief of Student Affairs, College of Foreign Languages, North China Institute of Science and Technology, Beijing, China; research fields: economic policy, foreign language, education policy, teaching pedagogy.

Shizhou Feng, B.A. candidate, Public Health Studies, Muskingum University, Ohio, USA, Bachelor of Engineering candidate, Safety Engineering, North China Institute of Science and Technology, Beijing, China; research fields: economic policy, public health studies.

Anyi Wang, B.A. candidate, Public Health Studies, Muskingum University, Ohio, USA, Bachelor of Engineering candidate, Safety Engineering, North China Institute of Science and Technology, Beijing, China; research fields: economic policy, public health studies.

Zijing Xu, B.A. candidate, Public Health Studies, Muskingum University, Ohio, USA, Bachelor of Engineering candidate, Safety Engineering, North China Institute of Science and Technology, Beijing, China; research fields: economic policy, public health studies. 
access to loans. MREs are defined as private owner-operated non-franchise retail businesses with a single location employing fewer than five individuals outside of the members of the owner's family (Huber et al., 2017). An m-payment refers to any form of payment "where a mobile phone is used to initiate, authorize, and confirm an exchange of financial value in return for goods and services" (Au \& Kauffman, 2008). The authors see m-payments as a leapfrogging technology that is changing the face of MREs and allowing them to compete more directly with larger more established retail outlets. We also explore the nature of MRE owners' entrepreneurial motivations and how this influences the decisions they make.

This paper builds on two previous articles on MREs in China. In the most recent article, we found approximately $90 \%$ of MREs were accepting at least one form of m-payment. Of those merchants who accepted m-payments, 87.4\% reported they believed it increased business (Ji, Huber, X. Xu, \& Z. Xu, 2017). The previous article documented the explosive growth of m-payment acceptance from almost no one a few years ago to a form of payment overwhelmingly accepted and this paper builds on that finding by exploring reasons MREs are accepting m-payments. Two earlier articles chart a decline of MREs accepting credit cards as m-payments gain, in popularity suggesting m-payments are not just a new form of payment but rather a potential replacement for bank and credit cards. In a 2017 survey, 59.2\% of MREs accepted bank cards (Huber et al., 2017). In a later survey of MREs, bank card acceptance rates declined to 34.8\% (Ji et al., 2017). We explore whether this trend is continuing or if credit card acceptance rates have leveled off.

The first survey in 2017 found an unlikely $41.6 \%$ of respondents claiming an ability to secure a loan to support their business (Huber et al., 2017). This ran counter to a robust literature that demonstrates how hard it is for non-state owned firms in general and small businesses in particular have in securing a traditional business loan. We hypothesized that respondents might be conflating business loans from a state run bank with informal loans, such as from family, repurposing mortgages as business loans, private bank loans, or local bank loans. The second survey differentiated between formal business loans and other funding mechanisms. We found 7.9\% of MREs claimed they could secure a traditional business loan (still higher than we anticipated). However, 52.9\% reported using an informal mechanism to substitute for a traditional business loan (Ji et al., 2017). Since there is limited literature on informal loans obtained by MREs, we asked the questions again to get more data on opportunities for improvement for China's banking sector.

\section{Access to Credit}

China's government has long been aware the problem SMEs have in obtaining bank loans and worked to address this issue. SME financing was explicitly added to the national development agenda, which in 2003, resulted in the "SMEs promotion Law" (Chong, Lu, \& Ongena, 2013). The paperwork required to get a bank loan serves as an impediment. To cite one example:

The Bank of China requires the following documentation for all business loans: qualification documents (ID cards, business licenses, etc.); financial statements of the operation (or operating income certificates); tax receipts; official certification of stable income and employment; and additional documentation as requested. (Bank of China, n.d.)

It is possible that m-payment transaction records can assist banks in determining whether MREs are credit-worthy.

Others have consistently found that limited access to traditional business loans lead SMEs to use less formal sources of credit since they are often locked out of the traditional banking infrastructure (Chan \& Lin, 
2013). Chan and Lin (2013) found $89 \%$ of the SMEs they interviewed funded their venture without a loan from a state-run bank. Others discovered the central role family plays in funding SME founding and development. "The household and extended family tend to provide primary sources of start-up capital. Another study found that $40 \%$ of SMEs surveyed had at least one family investor; $19.6 \%$ had two" (Pistrui, Huang, Oksoy, Jing, \& Welsch, 2001, as cited in Ji et al., 2017).

There is a good deal of speculation as to the causes. "Common explanations include a lack of interest on the part of banks to serve SMEs, immature credit markets, information asymmetry, skewed credit allocation that favors SOEs over private enterprises, and the slow development of the venture capital market" (Liu \& Huang, 2016, as cited in Ji et al., 2017). The problems MREs face are also structural in nature, given the high risk MREs face of going bankrupt and the increased risk this poses for banks considering loaning money to MREs. One study that looked at SMEs found $23.7 \%$ of their sample failed within in two years and $52.7 \%$ of SMEs in their sample left the market within four years due to business failure, bankruptcy, or for other reasons (Duan, Han, \& Yang, 2009).

Exploring what types of financing MREs are able to access and how they fill the gaps when shut out of traditional bank loans will paint a fuller picture of business financing in China and help identify areas state-run banks can further enhance economic growth. Despite the risks inherent in loaning funds to SMEs in general and MREs in particular, insufficient funding limits both the growth potential of SMEs as well as their contribution to job creation (Chow \& Fung, 2000). If MREs cannot get a formal bank loan, they must rely on borrowing from the informal credit market (The Chinese Academy of Social Sciences, 1996). Although the informal credit market has higher costs, it has become an important source of external financing for MREs (Chow \& Fung, 2000).

\section{The Adoption of M-Payment Technologies}

M-payments have expanded rapidly in many parts of the world, including China. An m-payment is any payment where a mobile phone is used to initiate, authorize, and confirm an exchange of financial value in return for goods and services (Au \& Kauffman, 2008). Using m-payment, a person with a wireless device could pay for items in a store or settle a restaurant bill efficiently and without interacting with any staff member. According to the China Third Party Mobile Payments Market Quarterly Monitoring Report (Analysys, 2018), China's m-payment transactions have exceeded the 40 trillion yuan (approx. USD $\$ 5.87$ trillion) threshold for the first time. What is more, $89.9 \%$ of micro-retail enterprises (MREs) in China are accepting m-payments to enhance their business ( $\mathrm{Ji}$ et al., 2017). M-payments create a distinctive value for both consumers and merchants (Lai \& Chuah, 2010). Readers unfamiliar with m-payments outside of the United States might be surprised since they have not been adopted at the same rate. At least, some of the difference can be explained by the decision to adopt one of two competing m-payment technologies. Many m-payment providers in the west prefer near field communication (NFC) technology which is generally faster, more flexible, and more secure whereas many developing nations (including China) have opted for Quick Response (QR) Code technology which is readable by more phones and allows for the scanning of a paper image which greatly reduces the technology required to accept m-payments from customers.

Whether m-payments are a marginally superior technology that will be added to the options customers have to pay for goods or whether they represent a meaningful breakthrough that will change MREs in fundamental ways requires a determination of how significant m-payments are. The authors use the Technology 
Acceptance Model (TAM) to examine perceived usefulness and perceived ease of use of m-payments to help gauge the importance of m-payments to MREs. TAM is a popular research model to predict use and acceptance of information systems and technology by individual users. In the TAM model, there are two factors-perceived usefulness and perceived ease of use that determine adoption rates and user acceptance. Davis (1989) defined perceived usefulness as the prospective user's subjective probability that using a specific application system will enhance his or her job or life performance. Perceived ease of use can be defined as the degree to which the prospective user expects the target system to be free of effort.

\section{Methods}

The authors surveyed 1,998 MREs in four Chinese cities. A 15-question instrument was developed and translated into Mandarin. Surveys were administered in person during a six-week period in June and July of 2018. Surveys were administered in the cities of Binzhou, Urumchi, Shenzhen, and Beijing. The cities were chosen to provide geographic and economic diversity. Binzhou is in east China, Urumchi is in northwest China, Shenzhen is located in south China, and Beijing is located in north China. Beijing is the capital of China, Shenzhen is a first-tier city in Guangdong Province, Binzhou is a third-tier city in Shandong Province, and Urumchi is a third-tier city in the Xinjiang Uygur Autonomous Region. The diversity allows tests of whether MRE development varies from tier-one to tier-three cities.

The first part of the survey had two identifying questions answered by the researchers. First, the location of the MRE was noted (city level) and second the MRE was classified as one of seven types of businesses: convenience store, souvenir (tourism), specialty retail (domestic market), restaurant, vender, service, or household goods store. This allows the researchers to determine how MREs in different cities and/or different sectors of the retail market might differ.

The second part of the survey focused on m-payments and credit cards. Respondents were asked which m-payment forms (if any) they accepted along with perceived advantages of m-payments (assuming they accepted them). We also asked questions for MREs who did not accept m-payments as to why they do not accept them. We inquired if they accepted credit cards and if not, why. This section explored MREs' preferred payment methods, how well they were connected to the digital economy, and potential roadblocks they face.

The third section of the survey focused on bank loans. Respondents were asked whether they had ever taken out a bank loan from one of the state-run banks to support their business, whether they ever took out any other type of loan and used the funds to support their business (apartment mortgage, local bank loan, family/friends, private commercial bank loan, or type of bank not listed), and whether they had ever used the transaction records from their m-payments accounts to help they get a loan if they had taken a loan. The purpose of this section is to explore the access of bank loan for MREs in China, and the extent to which m-payments help getting loans.

The final section of the survey asked respondents what was the primary reason they decided to open their business (more money from self-employment, desire to become a boss, greater independence and freedom from an entrepreneurial lifestyle, or no better choice for a job, what payment methods they preferred and what they believed were the effects of different payment methods on their business). These questions sought to better understand whether MRE owners are intentional entrepreneurs and how MREs are coping with a changing economy and their view about the future. 


\section{Findings: M-Payment Acceptance by MREs}

M-payment acceptance by MREs is almost universal. Ninety-eight point five percent of businesses surveyed accept at least one form of m-payment; $81.8 \%$ reported that m-payments were either "very important $(27.4 \%)$ or "somewhat important" (54.5\%). Only $2.6 \%$ of respondents claimed m-payments were either "somewhat unimportant $(1.7 \%)$ or "very unimportant" $(0.05 \%)^{1}$. Respondents generally felt m-payments were "very secure" $(19.9 \%)$ or "somewhat secure" (53.3\%). Only $2.8 \%$ felt m-payments were either "somewhat insecure" $(2.5 \%)$ or "very insecure" $(0.3 \%)^{2}$. Only $1.9 \%$ of respondents reported "no advantage of accepting m-payments". Of those that felt there were advantages (respondents could say "Yes" to more than one), 70.2\% cited "faster transaction time", 66.8\% said "customer preference for m-payments", 54.9\% said "avoid fraud abuses", 20.9\% said "customers spend more money when using m-payments", 13.1\% cited "getting new customers through online coupons or advertising on m-payment platforms" and $3.9 \%$ said "some other advantage not listed".

M-payments have become an important part of doing business in China for MREs. Very few MREs see them as unimportant and most see them as secure. Advantages of m-payments track well with Davis's Technology Adoption Model (TAM) looking at both perceived usefulness and perceived ease of use. The fact that $70.2 \%$ cite faster transactions and less than $3 \%$ believe m-payments are not secure indicates this technology satisfies the "ease of use" criteria. The high percentage citing customer preference for m-payments and the ability to avoid fraud by using this technology fit well with the TAM requirement that the technology have perceived usefulness. The authors see m-payments as a leapfrogging technology potentially allowing China to grow their consumer and service economy quicker than would otherwise be possible.

To identify a technological development, as "leapfrogging" is to say, it bypasses certain processes of human capacity accumulation and fixed investment to narrow the gap in productivity and output between industrialized and developing countries (Steinmueller, 2001). Leapfrogging technology can have an impact on the lives of people in different industries. Connectivity is one example of this. Millions of Africans who have never had a home phone use a mobile phone. A recent study found that mobile payments have helped 194,000 Kenyans escape extreme poverty in the past eight years (Suri \& Jack, 2016).

A technology must meet certain conditions to be considered leapfrogging:

(i) The difference in wage costs between the leading nation and potential challengers must be large. (ii) The new technology must, when viewed by experienced producers, appear initially unproductive compared with the old. (iii) Experience in the old technology must not be too useful in the new technology. (iv) The new technology must ultimately offer the possibility of substantial productivity improvement over the old. (Brezis, Krugman, \& Tsiddon, 1991)

Those conditions appear to have been satisfied in the case of m-payments over credit cards or case. Wage differences are large; the technology has not been adopted quickly in the west compared to developing nations (partly due to NFC being the standard in the west and QR Code being the standard in most developing countries); experience in accepting credit cards gives little advantage to companies considering accepting m-payments; and as demonstrated from the results, business owners report "substantial productivity improvement" with m-payments. It is however possible that m-payments are not replacing other forms of payments (mainly credit cards) but are just being added as an additional option. The authors attempt to control

\footnotetext{
$15.6 \%$ reported m-payments were "neither important nor unimportant".

$223.6 \%$ reported m-payments were "neither secure nor insecure".
} 
for this rival hypothesis by asking about credit card usage. This is a question that has been asked in the previous two surveys we conducted, so we can track changes.

\section{Findings: Credit Card Acceptance by MREs}

The percentage of MREs accepting credit cards was 30.5\%. This is a decline from last year's survey (34.8\%) (Ji et al., 2017) and a large decline from the survey conducted in 2017 (59.2\%) (Huber et al., 2017). Of the 1,373 respondents who do not accept credit cards, $50.3 \%$ cited "a lack of easy access to the machine", $30.8 \%$ cited "personal reasons", $27.3 \%$ cited "high service fees", and 7.6\% cited "a lack of understanding of how to gain access to the technology". There was a difference in credit card acceptance between tier-one and tier-three cities; $43.6 \%$ of MREs in tier-one cities accepted credit cards and only 18.3\% of MREs in tier-three cities did so. The results show credit cards are being phased out by MREs as a payment option (albeit at a slowing rate) and suggest that m-payments are in fact serving as a replacement technology instead of an additional option.

The fact that less than $10 \%$ cite a lack of understanding about how to access the technology needed to gain access as a reason why they do not accept this payment type indicates that MREs are choosing to replace credit cards with m-payments because they see them as superior. M-payments that use QR Code technology (which is the case of the major m-payment providers in China) do not require expensive technology (or electricity) and the m-payment providers typically charge one tenth of one percent as a service fee which is substantially lower than credit card companies charge. Additionally, respondents were asked which payment method they preferred customers use. $19.2 \%$ had no preference. Of the $80.8 \%$ who did have a preference, $83.5 \%$ preferred customers use m-payments, $12.3 \%$ preferred customers use cash, and $4.2 \%$ preferred customers pay with credit cards. Finally, respondents were asked which payment types lead to increases in impulse purchases. Forty-seven point three percent of respondents said m-payments would lead to more impulse buying, 15.7\% said credit cards, and $2.7 \%$ said cash would lead to more impulse purchases. This all adds evidence to support the hypothesis that m-payments represent a leapfrogging technology for the retail sector in China.

\section{Findings: Access to Loans for MREs}

The survey asked several questions regarding loans. First, respondents were asked, "Have you ever taken a business loan from one of the state-run banks (The Bank of China, China Construction Bank, Agricultural Bank of China, Bank of Communications, or Industrial and Commercial Bank of China) to support your business?". Respondents were given three options: "Yes", "No, did not want one", and "No, could not get one". A surprisingly high $13.9 \%$ said they had received a bank loan from one of these state-run banks. Supplemental analysis revealed a large difference in where these businesses were located though. Approximately equal numbers of surveys were administered in four cities (Beijing, Shenzhen, Binzhou, and Xinjiang). The two first tier cities (Beijing and Shenzhen) accounted for $91.7 \%$ of all loans from a state-run bank. It appears easier than initially thought to get a loan from a state-run bank but only in a few select tier-one metro areas. Of the 1,013 surveys administered in Binzhou and Xinjiang, fewer than 2.3\% of MREs were able to secure a bank loan. However, of the 986 surveys administered to MREs in Beijing and Shenzhen, 15.5\% were successful in securing a business loan. Access to the credit markets appears extremely uneven and locational dependent.

The second question on loans attempted to get at less conventional, higher cost, and shadow forms of lending. We asked, "Have you ever taken any other type of loan to support your business (Check all that 
apply)?" Respondents answered "Yes" to an apartment mortgage to be used to support business (2.5\%), a private commercial bank loan (4.9\%), a loan at a type of bank not listed (10\%), local bank loan (12\%), and loan from family and friends (37.5\%). The final question on loans was "if you have taken a loan, have you ever used the transaction records from your m-payments accounts to help secure the loan?" Seven point six percent of respondents said they had done so.

Of those who did receive a loan from a state-run bank, they were much more likely to be a convenience store (35.1\% compared to $18.8 \%$ for the full sample), more likely to accept credit cards (55.3\% compared to $30.7 \%$ for the full sample) but were similar to the whole sample on the other questions including whether they had taken out a loan from family and friends ( $40.9 \%$ compared to $37.5 \%$ for the full sample). Those who had not taken a loan from a state-run bank because they did not want one tended to be slightly less likely to take out a loan of any kind but otherwise similar to the entire sample. Those who did not have a loan from a state-run bank but had tried to get one were less likely to accept credit cards (17.8\% compared to $30.7 \%$ for the entire group), and somewhat more likely to have taken out an alternative loan, especially from family and friends (52.7\% compared to $37.5 \%$ for the full sample).

\section{Findings: Patterns of Entrepreneurship for MREs}

The survey included a question asking respondents to give the primary reason they decided to open their business. This question was included because some have argued that motivation should be associated with entrepreneurial entry into business in China. Motivation plays an important role in individual self-employment decision-making (Baumol, 1968). In the Western framework, motivations underlying entrepreneurial entry include greater independence in an entrepreneurial lifestyle, getting more money from self-employment, desiring to be a boss, and no better choice for a job (Carter, Gartner, Shaver, \& Gatewood, 2003; Reynolds \& Curtin, 2008). Self-employment provides a path to lower unemployment and poverty, as suggested by the disadvantage theory in the case of minorities in the U.S. (Light, 1972; Sanders \& Nee, 1987; Wilson, 1987). Of the 1,998 surveys administered, we collected 1,627 where the person interviewed was the founder of the MRE and able and willing to answer the question. Of this group, $65.8 \%$ said they wanted to make more money, $17.2 \%$ valued the greater independence and freedom an entrepreneurial lifestyle offered, $10.3 \%$ desired to be their own boss, and $6.6 \%$ felt they had no better choice for a job.

Those motivated to make more money were less likely to come from tier-one cities where there are more job opportunities, slightly less likely to accept credit cards (23.3\% compared to $30.7 \%$ for the full sample), but otherwise similar to the entire sample. Those motivated by greater independence and freedom were more likely to have taken out a loan from a state-run bank (17.9\% compared to $13.9 \%$ for the full sample). Their ability to value independence may have been influenced by access to credit which increases business opportunities. Those who valued being a boss were somewhat more likely to accept credit cards $(41.1 \%$ compared to $30.7 \%$ for the full sample) and more likely to take out different types of loans (from a state bank $15.5 \%$ compared to $13.9 \%$, from a local bank, $19 \%$ compared to $12 \%$, from a private commercial bank $11.9 \%$ compared to $4.9 \%$, from a bank not listed $14.9 \%$ compared to $10 \%$, and from family and friends $49.4 \%$ compared to $37.5 \%$ ). The only exception was an apartment mortgage to support their business which was virtually tied (2.4\% for this group and $2.5 \%$ for the full sample). Those seeking to be a boss tend to have larger expansion plans that may be explained by their desire to access credit in all forms. Those who felt they no better choice for a job tended to operate a MRE classified as a vender or service since these tend to be possible with lower starting costs. They 
were slightly less likely to accept m-payments (95.4\% compared to $98.5 \%$ for the full sample) which may be due to this group not being among early adopters of technology. They were less likely to accept credit cards (23.1\% compared to $30.7 \%$ for the full sample) and less likely to have taken out loans of all kinds expect from family and friends ( $46.3 \%$ compared to $37.5 \%$ for the full sample).

\section{Conclusions}

The authors have conducted surveys of MREs over three years and during that time; m-payments have gone from being a payment option some accepted to a payment option not only accepted by virtually all MREs (98.5\%), but the preferred method of payment for most (83.5\%) and important for their business (81.8\%). There are good reasons for this. For MREs, accepting mobile payments can improve the customer experience, simplify record keeping, and reduce transaction costs. The need for cash or credit cards is eliminated and there is no need to make change. M-payments are more secure than other forms of payment for both the customer and the retailer. The authors see m-payments as a leapfrogging technology potentially allowing China to grow their consumer and service economy quicker than would otherwise be possible. The results of this study provide good evidence that Davis's Technology Adoption Model (TAM) test of perceived usefulness and ease of use has been met. The fact m-payments are replacing credit cards and not just being added as an additional payment option lends additional credibility to the case that they represent a leapfrogging technology.

Access to loans for MREs is much better than generally imagined but only for those in tier-one cities. There has long been a gap in China between the fortunes of those living in cities and the countryside in general and between those living in tier-one cities and those living in tier-two or tier-three cities. There are many established reasons for this gap and some of the reasons are structural and hard to combat. It does seem however that one contributing factor for differences in opportunity is access to loans which is much more robust in tier-one cities than elsewhere. Increased access to loans for those living outside tier-one cities would help improve the economic condition of these places and lessen the gap between tier-one cities and the rest of the country. China has developed many excellent programs to improve the lives of those living outside tier-one cities. Changes to banking regulations encourage more loans to SMEs in general and MREs in particular located outside tier-one cities has the potential to yield positive results.

Expanding the research on this topic should include a more in-depth exploration of the importance of m-payments as a leapfrogging technology. This study provides evidence m-payments serve MREs as a leapfrogging technology that offers them lower business costs and higher sales. More research is needed to replicate and confirm this finding. The relationship between access to state-run bank loans and the size and location of the city the MRE is located in should also be explored. The evidence from this 1,998 person survey is clear but it should be stressed that this is only one study and additional research should be conducted to replicate and confirm this important finding. Finally, the importance of entrepreneurship for the formation of

MREs needs to be explored in more depth. The authors asked questions on this and were able to gather some promising initial data but no firm conclusions could be drawn as to how different entrepreneurial motivations by the founders of these businesses might impact their success or direction.

\section{References}

Analysys. (2018). Digital process analysis of mobile payment industry. Retrieved from https://www.analysys.cn/article/analysis/ detail/20018972 
Au, Y. A., \& Kauffman, R. J. (2008). The economics of mobile payments: Understanding stakeholder issues for an emerging financial technology application. Electronic Commerce Research and Applications, 7(2), 141-164.

Bank of China. (n.d.). Personal investment business loans Requirments. Retrieved from http://www.boc.cn/pbservice/pb2/200806/ t20080625_719.html

Batinge, B., Musango, J. K., \& Brent, A. C. (2017). Leapfrogging to renewable energy: The opportunity for unmet electricity markets. South African Journal of Industrial Engineering, 28(4), 32-49.

Baumol, W. (1968). Entrepreneurship in economic theory. American Economic Review Paper and Proceedings, 58, 64-71.

Berger, A. N., \& Udell, G. F. (2002). Small business credit availability and relationship lending: The importance of bank organisational structure. The Economic Journal, 112(477), 32-53.

Brezis, E., Krugman, P., \& Tsiddon, D. (1991). Leapfrogging: A theory of cycles in national technological leadership. The American Economic Review, 83(5), 1211-1219.

Carter, N. M., Gartner, W. B., Shaver, K. G., \& Gatewood, E. J. (2003). The career reasons of nascent entrepreneurs. Journal of Business Venturing, 18(1), 13-39.

Chan, S. H., \& Lin, J. J. (2013). Financing of micro and small enterprises in China: An exploratory study. Strategic Change, 22(7-8), 431-446.

Chong, T., Lu, L., \& Ongena, S. (2013). Does banking competition alleviate or worsen credit constraints faced by small- and medium- sized enterprises? Evidence from China. Journal of Banking \& Finance, 37(9), 3412-3424.

Chow, C. K., \& Fung, M. K. (2000). Small businesses and liquidity constraints in financing business investment. Journal of Business Venturing, 15(4), 363-383.

Davis, F. D. (1989). Perceived usefulness, perceived ease of use, and user acceptance of information technology. MIS Quarterly, 13(3), 319-339.

Duan, H., Han, X., \& Yang, H. (2009). An analysis of causes for SMEs financing difficulty. International Journal of Business and Management, 4(6), 73-75.

Gallagher, K. S. (2006). Limits to leapfrogging in energy technologies? Evidence from the Chinese automobile industry. Energy Policy, 34(4), 383-394.

Huber, W., Brady, M., Deng, Q., Wei, X., Zhang, M., Zhang, R., \& Zhang, X. (2017). Micro-Retail enterprises in China: Challenging the stereotype. Journal of US-China Public Administration, 14(2), 74-82.

Ji, Y., Huber, W., Xu, X., \& Xu, Z. (2017). Micro-Retail enterprise in china: Healthier and more mature. Journal of US-China Public Administration, 14(6), 313-320.

Lai, P., \& Chuah, K. (2010). Developing an analytical framework for mobile payments adoption in retailing: A supply-side perspective. Proceedings from Fourth International Conference on Management of E-Commerce and E-Government (ICMeCG 2010), October 23-24, Chengdu, China.

Light, I. (1972). Ethnic enterprise in America. Berkeley, CA: University of California Press.

Liu, C., \& Huang, X. (2016). The rise of urban entrepreneurs in China: Capital endowments and entry dynamics. Growth and Change, 47(1), 32-52.

Pistrui, D., Huang, W., Oksoy, D., Jing, Z., \& Welsch, H. (2001). Entrepreneurship in China: Characteristics, attributes, and family forces shaping the emerging private sector. Family Business Review, 14(2), 141-152.

Reynolds, P. D., \& Curtin, R. T. (2008). Business creation in the United States: Panel study of entrepreneurial dynamics II initial assessment. Foundations and Trends in Entrepreneurship, 4(3), 155-307.

Sanders, J. M., \& Nee, V. (1987). Limits of ethnic solidarity in the enclave economy. American Sociological Review, 52(6), $745-773$.

Steinmueller, W. E. (2001). ICTs and the possibilities for leapfrogging by developing countries. Journal of International Labour Review, 140(2), 193-210.

Suri, T., \& Jack, W. (2016). The long-run poverty and gender impacts of mobile money. Science, 354(6317), 1288-1292.

The Chinese Academy of Social Sciences. (1996). Survey report on private enterprises and entrepreneurs in 1995. Mimeo, Beijing.

Wilson, W. J. (1987). The truly disadvantaged: The inner city, the underclass and public policy. Chicago, IL: University of Chicago Press. 